\title{
Trend of IASB Project on the Distinction between Equity and Liabilities: The Case for Cooperatives and Continental European Firms
}

\author{
Roberto Maglio ${ }^{1, *}$, Francesco Agliata ${ }^{2}$, Danilo. Tuccillo ${ }^{2}$ \\ ${ }^{1}$ Department of "Economia Aziendale", University of Naples Federico II, Italy \\ ${ }^{2}$ Department of "Economia", Second University of Naples, Italy
}

Copyright $\odot 2017$ by authors, all rights reserved. Authors agree that this article remains permanently open access under the terms of the Creative Commons Attribution License 4.0 International License

\begin{abstract}
The aim of this paper is to amend the research on the economic consequences of the proposed changes in equity and liabilities classification. The distinction between equity and liabilities is a challenging question for international standard setters. On this topic, the IASB and the FASB have developed a long-term project with the aim of addressing unresolved issues around classifying financial instruments as either equity or liabilities. With this regard, many approaches, which involve various effects on the gearing and on the reported earnings, have been proposed. In its 2008 discussion paper "Financial Instruments with Characteristics of Equity" the IASB exposed the alternative methods previously presented by the FASB in former Preliminary Views. Among the three different approaches, the Basic Ownership Approach was recommended in consideration of its simplicity with the hope of reducing structuring opportunities. Also the EFRAG gave its contribution to this debate by issuing its own discussion paper; it suggested a new classification method, the Loss Absorption Approach.
\end{abstract}

Keywords Equity, Financial Instrument, IAS/IFRS, Performance, Fair Value, Financial Reporting

\section{Introduction}

Worldwide standard setters have been discussing new concepts for distinguishing between equity and liabilities for about two decades now. The main objective of this research is to describe the different approaches to classification and distinction between equity to liabilities; also we want to mention the implications for economic and financial terms of the proposed changes in equity / liabilities classification. To do so, we analyze comment letters written in response to the discussion paper "Financial Instruments with Characteristics of Equity" by applying a content analysis based approach.

Classification of financial instruments as equity or liability is a very complex issue, as evidenced in: the FASB (1990) Discussion Memorandum, the FASB (2000) Exposure Draft, Accounting for Financial Instruments with Characteristics of Liabilities, Equity, or Both; the issuing of FASB Statement 150 and the subsequent decision to defer application of the statement's provisions to mandatorily redeemable shares of certain nonpublic entities and certain mandatorily redeemable non-controlling interests, and the recent amendment to IAS 3 (FASB, 1990; FASB, 2000; FASB, 2003; IASBa, 2008; IASBb, 2008) [1], [26, 27, 28, 29].

To highlight the distinct classification and valuation issues across different types of instruments, we distinguish and define below the following classes of financing instruments:

- Simple

- Compound, with:

- $\quad$ separable components

- inseparable components

- Hybrid

The most difficult issues arise with inseparable compound and hybrid financing instruments.

A simple financing instrument has a single component that is either straight debt or common equity. A compound financing instrument consists of multiple components; at least one is a liability and one is equity. The components of a compound financing instrument may be separable, meaning that the components can be independently valued through their lives. A bond with an attached warrant is a separable compound financing instrument. Alternatively, when the components of a compound financing instrument are inseparable, the instrument has liability and equity components that can be defined separately for valuation purposes, but the instrument's ultimate payoff is either as a liability or as equity, not both. Convertible debt is an inseparable compound financing instrument. A hybrid financing instrument has characteristics of a liability and 
equity but does not have distinct components that are straight debt or common equity. Preferred stock is a hybrid instrument.

The FASB and IASB long-term project on liabilities and equity is seeking to address unresolved issues around classifying financial instruments as equity or liabilities. As part of this process, the FASB issued Preliminary Views, Financial Instruments with Characteristics of Equity (FASB, 2007) [2], describing three possible approaches and from these, has selected the Basic Ownership Approach (BOA).

The Basic Ownership Approach involves a narrow definition of equity, where only the most subordinate financial instrument would be classified as equity; with the holders of such equity instruments viewed as the owners of the entity. An instrument (basic ownership instrument) would be classified as equity where it had both of the following characteristics:

a The holder has a claim to a share of the assets of the entity that would have no priority over any other claims if the issuer were to liquidate on the date the classification decision is being made; and

b The holder is entitled to a percentage of the assets of the entity that remain after all of the higher priority claims have been satisfied. The holder's share depends on its share of the total claims with the lowest priority and has no upper or lower limit except for the amount of assets available.

In February 2008, the IASB published a Discussion Paper, comprising the three FASB approaches and a description of the current IAS 32 concept (IASBb, 2008) [3]. At the current state, the IASB does not present an own approach, but seeks comments on the approaches developed and proposed by the FASB

In 2008 Working Groups of EFRAG's Proactive Accounting Activities in Europe (PAAinE) Initiative and the German standard setter ASCG published another Discussion Paper on the same topic, containing yet another approach (EFRAG, 2008) [4]. Under this approach, named Loss Absorption Approach (LAA), "capital is deemed risk capital and, thus, presented as equity if it is available for loss absorption from an entity's perspective"; the distinction between equity and liabilities is based exclusively on the ability or inability of capital to absorb (accounting) losses incurred by the entity.

The Loss Absorption Approach concentrates on the buffer function of equity and requires only participation in losses, not necessarily also in profits.

It is interesting to note that equity is narrower under BOA (the approach proposed by the FASB and IASB) than under LAA (the approach proposed by the EFRAG) (Kampmann-Schmidt, 2008) [5].

In the first section, the two pre-eminent equity theories are presented; in particular the implications of the proprietary theory and entity theory are shown. In the second section, the main empirical research are highlighted, showing the lack of empirical research on the topic. In the third section, the content of the comment letters are analyzed and the geographical distribution of the approaches is highlighted. Finally, some considerations on the topic and the probable future developments are provided.

\section{The Equity Theories}

Theories of equity postulate how the balance sheet elements are related and have implications for the definitions of both liabilities and equity. The two prominent theories of equity - proprietary theory and entity theory - are well-known and imply unique relationships between assets, liabilities and equity.

The proprietary theory dates back at least as far as the early eighteenth century. The proprietary view of accounting was developed at a time when business firms were small and were mainly sole proprietorships and partnerships.

Under the proprietary theory, financial reporting is based on the premise that the owner is the primary focus of the financial statements. The proprietary theory views the net assets of the firm as belonging to the firm's owners, the liabilities are their obligations, and ownership equities accrue to the owners. Under this theory, equity is equal to the net worth of the owners. The proprietary theory relationship is articulated as

\section{Assets - Liabilities $=$ Equities}

Under traditional proprietary theory the distinction between debt and equity is absolute. This relates to the fact that proprietorship is determined as net assets.

Equity is not considered a liability of the entity to the proprietor except for bookkeeping purposes.

It does not allow for liabilities that are not either debt or equity because it does not allow the entity to have equity in itself as everything that is not debt must automatically be owners' equity.

This hardness of the distinction between debt and equity leads to a definition and disclosure of net income as 'net income to shareholders'. 'From the point of view of the proprietor any payment to an outsider necessary to the conduct of the business is a cost or an expense' (Chow, 1942, p. 157) [6]. Under a narrow interpretation of the proprietary concept even cash dividends to preferred shareholders represent an expense to the company (Sprouse, 1957, p. 376) [7].

Dissatisfaction with the orientation of the proprietary theory led to the development of the entity theory. The theory has been developed by Paton (Paton 1922) [8]. Under the entity theory, the firm and its owners are separate beings. Net worth of the proprietor is not a meaningful concept, because the entity is the centre of attention. The entity theory depicts the accounting equation as

$$
\text { Assets }=\text { Equities (including liabilities) }
$$

The entity theory views the entity as something separate 
and distinct from those who provide capital to the entity.

The assets belong to the firm itself; both liability and equity holders are investors in those assets with different rights and claims against them. According to the entity theory, there is no fundamental difference between liabilities and owners' equity.

Pure entity views of the firm do not distinguish debt from equity but shows liabilities in order of decreasing seniority.

\section{Prior Empirical Research}

Academic research on the equity-liability distinction is quite scarce. Apart from contributions from academics to the standard setting process, empirical research is fragmentary and focused on narrow issues.

This finding is quite surprising, being the economic consequences of the equity/liabilities classification of financial instruments relevant.

Indeed, the decision of classifying a financial instrument as a liability, instead of equity, will have impact on gearing, on reported net earnings (as the dividends on financial instruments that are classified as a liability will appear on the profit and loss statement in the same way as interest payments do) and on debt covenants.

De Jong-Rosellon-Verwijmeren (2006) [9] have provided evidence that the implication of IAS 32, whereby most preference shares in the Netherlands qualify as a liability, is that the majority of Dutch firms with preferred stock outstanding choose to alter the specifications of their capital structure; firms do this either by buying back the shares $(52 \%)$, or by altering the specifications of the preference shares in such a way that the classification as equity can be maintained (19\%).

Their evidence is consistent with Engel-Erickson-Maydew (1999) [10] who examined whether firms are willing to accept higher financing costs in order to achieve a desired classification of their capital instruments.

Hopkins (1996) [11] investigates whether the balance sheet classification of financial instruments that include attribute of both debt and equity affects the stock price judgments of buy-side financial analysts; his study demonstrates that accounting classification seems to influence users' judgment of the financial statements.

Schroeder-Sevin-Schauer (2006) [12] reports that that compliance with SFAS 150 could cause some companies to be in default of their debt covenants or to experience large increases in interest costs.

The aim of this paper is to amend the research on the economic consequences of the proposed changes in equity/liabilities classification.

Zeff (1978) [13] portrays the upcoming consideration of the impact of accounting reports on decisions making in the standard setting process during the 1970s. Until the 1970s the standard setting process did not include any consideration of economic consequences. However, during the 1970s management became more open in its cooperation with the standard setting bodies and focused on the argument of economic consequences.

Moreover, the FASB's conceptual framework included "probable economic or social impact" among the other "qualities of useful information" than relevance, measurability, reliability and comparability. Such evidence demonstrates that the economic consequences perspective has become accepted as a valid substantive policy issue.

The standard setting bodies have organized the standard setting process more open in reaction to the increasing involvement of third parties. Economic consequences became part of the standard setting process, and moreover, were accepted as a policy.

Since the identification of this issue, there have been a number of studies that have investigated the economic consequences of accounting standards on the following issues:

- the accounting for employee stock option (Guay -Kothari- Sloan 2003) [35];

- the economic consequences of accounting for stock-based compensation (Dechow- Hutton-Sloan 1996) [14];

- the employers' accounting for postretirement benefits other than pensions (Khurana-Loudder, 1994) [36];

- the effect of statement No. 87 on the financial reports of early adopters (Stone -Ingram 1988) [37];

- the further examination of the economic consequences of SFAS (Wasley-Linsmeier 1992) [38].

Usually the respondents to a Discussion Paper (or to an Exposure Draft) anticipate significant economic consequences; through the comment letters, the standard setters can obtain ex ante evidence on the potential economic consequences of the proposed accounting change.

Fehr-Fülbier (2009) [15] analyze the comment letters to the IASB discussion paper "Leases - Preliminary Views" to obtain and compare the respective views of material groups involved in lease accounting and also amend the research on economic consequences of the future lease reform.

\section{An Analysis of Comment Letters to the IASB Discussion Paper}

We analyze comment letters written in response to the discussion paper "Financial Instruments with Characteristics of Equity" by applying a content analysis based approach. Content analysis based research can be defined as a "research method that uses a set of procedures to make valid inferences from text. These inferences are about the sender(s) of the message, the message itself, or the audience of the message" (Weber 1990) [16].

Content analysis has also been used frequently in social sciences. In the field of accounting research this method has 
been applied for analyzing corporate communications, such as the letter to shareholders (e.g. Abrahamson - Amir (1996), Smith-Taffler (2000), see Jones -Hoemaker (1994) for a review of content analysis studies in accounting) [17], [33, 34]. There are two general approaches to content analysis: "form oriented" (objective) analysis, which involves the routine counting of words, concepts or themes; and "meaning oriented" (subjective) analysis, which focuses on inferring the underlying meanings present in the texts being investigated (Smith-Taffler 2000) [18].

Commentators have noted the limitations of the procedures of analysis that are just "form oriented" (e.g., Weber 1990) [19], claiming that the utility of content analysis lies mainly in its "meaning oriented" application. Form-oriented analysis is more objective, while meaning-oriented analysis provides richer insights into the text under analysis (Yen-Hirst -Hopkins (2007)) [20]. Our approach is a qualitative analysis with some quantitative elements.

We developed our hypothesis after reading an initial sample of 25 comment letters.

Several factors will affect the development of a new international accounting standard on the classification of issued financial instruments.

One of these factors is related to the recognized function, by different jurisdictions, to equity capital.

While in some countries, like the United States, equity does not play a role of prior importance in entity's life, in other countries it has a major organizational function.

As an example, dividend distribution of American companies does not depend on the level of equity but rather on financial tests.

Consequently we believe that the proposal of different classification methods, that affect the level of equity, would involve that some respondents in function of their legal system would have different economic incentives to lobby ${ }^{1}$.

The Basic Ownership Approach, that is the FASB and IASB preferred method, for instance, will strongly reduce the area of the equity; therefore we suppose that it will probably encounter a massive opposition from those respondents interested in preserving it.

Given these considerations, we assume that the reactions and the answers to the Discussion Paper of the IASB have been different in function of the nationality of respondents.

More specifically, in this analysis, respondents will be distinguished in two geographical areas: the Anglo-American area, where financial statements have only an informative function for investors, and the Continental-European area, mainly represented by French and German respondents.

This will lead to the first hypothesis:

1 Research has identified economic incentives for corporations to lobby standard setters on various accounting rules, particularly when they affect debt positions, broaden or limit management's ability to manage reported earnings, or affect management compensation (Francis, 1987; Georgiou, 2005 and 2010; Watts -Zimmerman, 1986) [21],[30, 31, 32]
Hp1: Is there a positive correlation between geographical provenance of respondents and accounting approach preferred?

The choice of regulating universally the classification of financial instruments, through a unique accounting approach to be used by any form of enterprise, probably will conflict with the characteristics of co-operative members' shares and co-operative ownership.

In particular, with concern to cooperatives, the matter of distinction between equity and liabilities is a matter of major importance, it observe that the application of the Basic Ownership Approach might involve that some cooperatives would result without ownership interests at all and thus without equity.

In consideration of the specific characteristics of cooperative shares, a part of the doctrine has promoted the issuing of a specific accounting standard on financial instruments issued by cooperatives. ${ }^{2}$

Hence the second hypothesis follows:

Hp2: Is there a positive correlation between affiliation of respondents to cooperative and accounting approach preferred?

The total amount of letters received by the European standard setter is $127^{3}$.

In order to implement the present research we have deemed useful to establish a one-to-on relation between respondents and letters; in other words, when a subject sent more than one letter, we have counted it as a unitary comment.

For this reason, 2 letters, which elaborated in more detail the position of a previous letter sent by the same respondent, have been excluded from the analysis.

Besides, it has been excluded as well 1 comment letter, because it did not express a well-define position.

In summary we examined 124 comment letters.

In table 1 it is shown the geographical distribution of comment letters in function of the nationality of respondents:

With the intent to evaluate the reaction to the IASB Discussion Paper, we have preceded the analysis by coding the positions expressed in letters.

Therefore, we classified them in different categories according to their overall position. In particular we focused on the main approach proposed by FASB, and undertaken by IASB in his Discussion Paper (the BOA), and the contrasting approach proposed by EFRAG (the LAA).

2 "The differing ownership, governance and economic model that co-operatives exhibit would suggest the value of exploring the development of a separate set of co-operative financial instruments classification principles". Lopez Espinosa Maddocks - PoloGarrido (2009) [22].

3 The number of respondents to the analogous document of the FASB amount to 66. In both cases the response rate is considered quite low. This shows that probably the issue presented in those documents has not been considered of major importance and/or that the discussion is still at an early stage. We must consider that the Discussion Papers are preliminary documents in comparison to the Exposure Drafts. Tandy -Wilburn (1992), Constituent participation in standard setting: The FASB's first 100 statements, observe that comment letters received during the elaboration of the first 100 FASB accounting standards, between 1973-1988, were in average 138 [23]. 
Table 1. Geographical Distribution of Comment Letters

\begin{tabular}{|c|c|c|}
\hline \multicolumn{3}{|c|}{ Geographical Distribution of Comment Letters } \\
\hline CONTRY & $\begin{array}{c}\text { Num. comment } \\
\text { letters }\end{array}$ & $\begin{array}{c}\text { Response rate } \\
\text { per country }\end{array}$ \\
\hline UK & 16 & $\mathbf{1 2 , 9 0 \%}$ \\
\hline USA & 9 & $\mathbf{7 , 2 6 \%}$ \\
\hline GERMANY & 9 & $\mathbf{7 , 2 6 \%}$ \\
\hline CANADA & 8 & $\mathbf{6 , 4 5 \%}$ \\
\hline INTERNATIONAL & 27 & $\mathbf{2 1 , 7 7 \%}$ \\
\hline FRANCE & 7 & $\mathbf{5 , 6 5 \%}$ \\
\hline JAPAN & 7 & $\mathbf{5 , 6 5 \%}$ \\
\hline AUSTRALIA & 6 & $\mathbf{4 , 8 4 \%}$ \\
\hline SWITZERLAND & 6 & $\mathbf{4 , 8 4 \%}$ \\
\hline $\begin{array}{c}\text { Countries with less than } 3 \\
\text { comment letters }\end{array}$ & 29 & $\mathbf{2 3 , 3 9 \%}$ \\
\hline TOTALE & $\mathbf{1 2 4}$ & \\
\hline
\end{tabular}

The categories defined are the following:

Table 2. The various approaches

\begin{tabular}{|c|c|c|}
\hline \multicolumn{2}{|c|}{ POSITIONS } \\
\hline 1 & NONE & Opposing Letters \\
\hline 2 & BOA & Basic Ownership Approach \\
\hline 3 & LAA & Loss Absorption Approach \\
\hline 4 & OTHER & Other Methods \\
\hline
\end{tabular}

Given these categories, we realized that letters usually expressed their positions with different degrees of support for a specific method.

Although some of them would recommend the immediate use of a specific approach, some others would present a more feeble preference. They would express just a general interest for a specific method asking for a deeper examination in future.

For this reason we structured this analysis in two levels. The first level of analysis implies classifying letters in the categories of LAA or BOA or OTHER only when they expressed a strong preference for those methods.

Otherwise they were considered in opposition to the proposed approaches.

Instead, with the second level of the analysis, we went more in depth with the coding, by reclassifying the opposing letters in the first three categories in case they expressed the interest for one of those methods.

The aim of the second level of analysis is to give an overall idea of the general acceptance of a specific model.

In other terms our choice to make a distinction between these two levels of analysis descends on the intent of representing as faithfully as possible respondents' positions.

In this paragraph the preferences expressed in the comment letters will be exposed regardless of the geographical provenance and the enterprise's form of respondents.

In this sense they will be referred to as aggregate preferences.

The first level of analysis shows that the $63 \%$ of subjects that responded to the IASB did not feel the necessity of adopting new classification methodologies for issued financial instruments.

This $63 \%$ includes those (32\%) who do not want to change the actual accounting principle of IAS 32 and those $(34 \%)$ asking for some change but opposing to the proposed approaches. These latest respondents do not believe that neither the three approaches proposed by IASB and FASB nor the method supported by EFRAG can be considered a suitable starting point for a successful reform of the classification system.

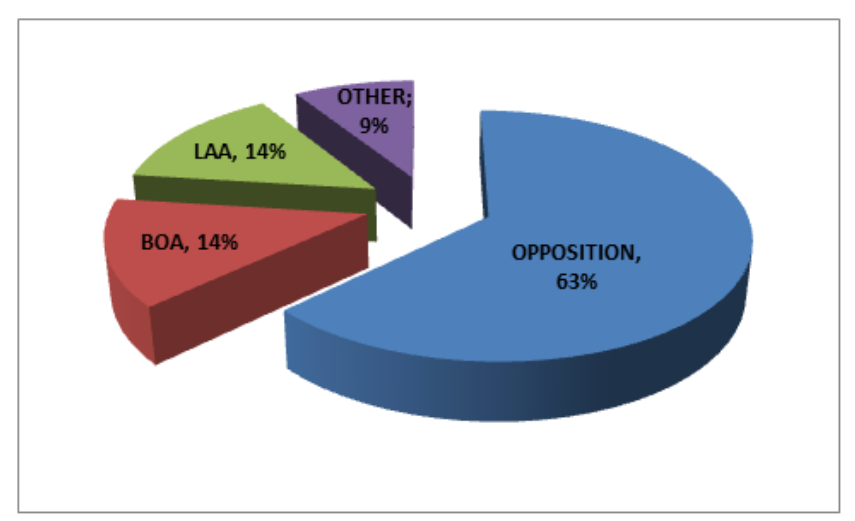

Graph 1. Distribution of aggregate positions: method preferred

They argue instead that the reform of the IAS 32 should necessarily be coordinated with the IASB Conceptual Framework project in order to develop in future an integrated system of consistent rules and definitions supported by a solid conceptual base.

An important result coming out from this analysis is that the method recommended by the two international standard setters (FASB and IASB), the Basic Ownership Approach, has been strongly opposed. It has collected just the $14 \%$ of preferences.

The FASB Preliminary Views and the IASB Discussion Paper claimed their position in favor of this method by praising its simplicity and thus its ability to reduce structuring opportunities ${ }^{4}$. Instead the Basic Ownership Approach has been criticized and considered over simplistic and unable to give a faithful representation of economic reality underlying events.

Furthermore, according to many respondents, simplicity has not been accepted as a significant aspect to be considered when choosing the best method to draw the correct border line between equity and liabilities.

4 FASB states "The basic ownership approach is designed to draw the necessary line in the simplest and most informative way that the Board could devise. Simplicity means making the reported information easy to understand by those who prepare, audit, and use that financial information. In this case, a valuable by-product of simplicity is that it would reduce the opportunities to structure very similar transactions or arrangements differently to achieve a different financial reporting result (structuring opportunities)." 
With concern to the Loss Absorption Approach, we registered an "approval rate" of $14 \%$ in a first level analysis; it is equal to BOA's rate.

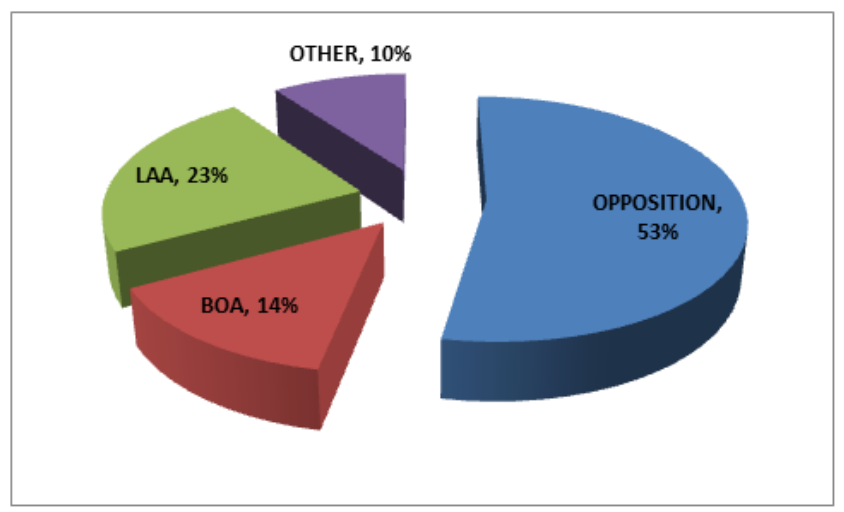

Graph 2. Distribution of aggregate positions: method worth interest

Nevertheless, by conducting the second level analysis we found out that this percentage of $14 \%$ increases up to $23 \%$, demonstrating a general positive attitude towards this methodology.

With the aim of conducting the analysis in function of the geographical provenance of respondents, two areas have been defined: Anglo-American area and Continental-European area.

Their composition is shown in the following table:

Table 3. Geographical areas

\begin{tabular}{|c|c|c|c|}
\hline \multicolumn{2}{|c|}{ ANGLO - AMERICAN } & \multicolumn{2}{c|}{ CONTINENTAL-EUROPEAN } \\
\hline USA & 9 & GERMANY & 9 \\
\hline AUSTRALIA & 6 & FRANCE & 7 \\
\hline NEW ZELAND & 3 & TOTAL & 16 \\
\hline CANADA & 8 & & \\
\hline UK & 16 & & \\
\hline TOTAL & 42 & & \\
\hline
\end{tabular}

58 Comment letters have been attributed to these two areas, representing the $47 \%$ of the total number of comments.

The next graph will present the geographical distribution of preferences expressed.

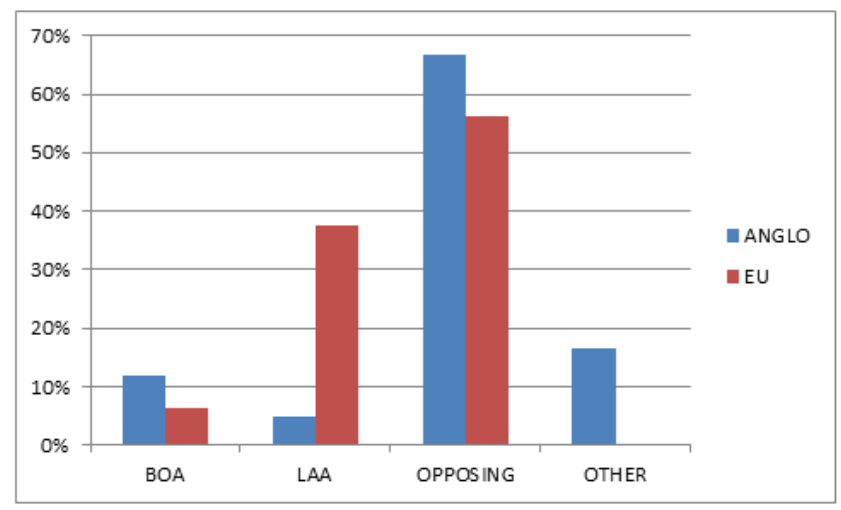

Graph 3. Geographical distribution of preferences
From a previous analysis of these results we have noted the presence of a certain correlation between geographical provenance and respondents' position.

Consistently with the analysis conducted at an aggregate level, for both the geographical areas, the majority of comments letters appears critical towards the methods proposed in the Discussion Paper.

Opposing comments are homogeneously distributed. The $67 \%$ of Anglo-American respondents and the 56\% of Continental European respondents would either object to the new methods or would ask for the maintenance of the actual IAS 32, sometimes with little amendments.

In contrast, we have noted that between letters in support of the Basic Ownership Approach or the Loss Absorption Approach there were some significant inequalities in terms of geographical distribution.

The following two graphs present these results: respectively the BOA's and LAA's geographical distribution.

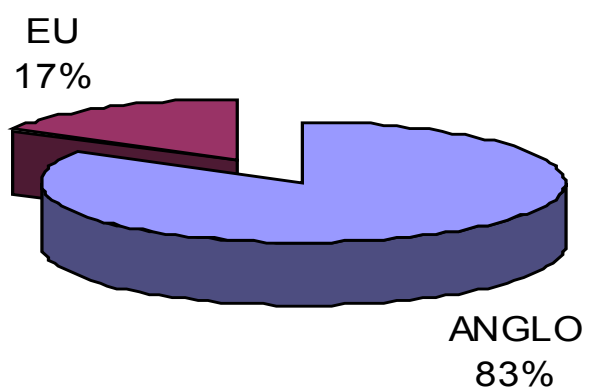

Graph 4. Geographical distribution of boa preferences

Graphs 4 shows that letters supporting the BOA are predominantly concentrated in the Anglo- American area: between those who prefer the Basic Ownership Approach, the $83 \%$ is of Anglo-American provenance.

Thus, we can affirm that it does exist a positive correlation between letters coming from Anglo-American organisms and preferences for the Basic Ownership Approach. As we remind, it is the approach that more strongly reduces the equity area.

With regard to the geographical distribution of the preferences in favor of the Loss Absorption Approach, we observed (Graph 5) that the majority (75\%) of letters promoting this methodology belong to subjects of the Continental-European area.

It is interesting to note that Continental European laws state rules about the minimum capital and the capital maintenance and this enhances the role of equity in entity's life, differently from Anglo-American laws ${ }^{5}$.

5 It is difficult to generalize about Continental Europe, because each country has had its own laws and accounting traditions and cultures. Nonetheless, a number of the countries have had some common features. Flower (2004) has enumerated a broad array of functions that company financial statements have historically fulfilled in Europe:

- The maintenance of capital - the regulation of dividends

- The monitoring of management - stewardship

- Information for investors

Information for the state 
Moreover German law grants the member of the firm (that is, the shareholder or partner) the right to cancel his membership; this applies to private partnerships, private limited companies, private limited partnerships and cooperative societies (mutual entities), except for the public limited liability companies. As a result, classification as liabilities of all member shares or partnership interests should be unavoidable under the Basic Ownership Approach.

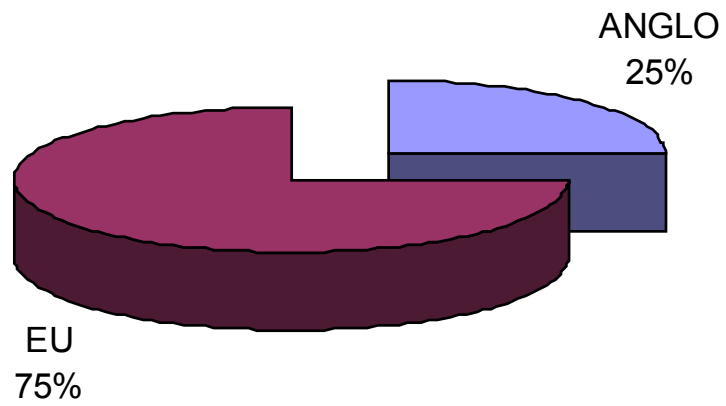

Graph 5. Geographical distribution of laa preferences

As shown by the graph above, the Loss Absorption Approach obtained an high rate of acceptance in the Continental Europe Area. Instead only the $25 \%$ of LAA's preferences comes from Anglo-American respondents.

Besides this, more interesting is noticing that all these Anglo-American subjects were in fact cooperatives.

As we will demonstrate in the next paragraph, by verifying the second hypothesis, this is not an accidental result: cooperatives would be strongly and negatively affected by the application of the Basic Ownership Approach whilst the Loss Absorption Approach would better fit their needs and would allow them preserving their level of equity.

This short digression should give us a deeper understanding of our results: respondents of Anglo-American provenance generally do not support the LAA unless they are cooperatives.

This is because, presumably in this case the position in support of the Loss Absorption Approach is not due to their geographical provenance but instead to their form of enterprise.

Therefore, we observed that there is a strong positive correlation between letters sent by respondents belonging to the area of Continental European and the Loss Absorption Approach.

Thus we can affirm that it does exist a correlation between geographical provenance of the respondent and the preference expressed in comment letters: $\mathrm{Hp} 1$ is confirmed.

The second phase of this research has the aim of analyzing letters in function of the enterprise's form of respondents.
It has focused on comment letters sent by cooperatives or by subjects responding on behalf of cooperatives. These letters are 15 and they are classified in the "cooperatives" category:

\begin{tabular}{|c|c|}
\hline \multicolumn{2}{|c|}{ COOPERATIVES } \\
\hline 1 & European Association of Cooperative Banks (EACB) \\
\hline 2 & Euro Coop \\
\hline 3 & General Confederation of Agricultural Co-operatives in the EU \\
\hline 4 & Cooperatives Europe \\
\hline 5 & Central Union of Agricultural Co-operatives and the Norinchukin \\
\hline 6 & Bank \\
\hline 7 & International Co-operative Alliance ICA \\
\hline 8 & Consumers' Coroperatives \\
\hline 9 & World Council of Credit Unions \\
\hline 10 & Fonterra Co-Operative Group Ltd \\
\hline 11 & National Cooperative Business Association \\
\hline 12 & GNC (GROUPEMENT NATIONAL DE LA COOPERATION) \\
\hline 13 & $\begin{array}{c}\text { Joint Comments of German Associations: VOEB, DGRV, BDI, } \\
\text { BStBK, BVR, DIHK, DSGV, VMEBF }\end{array}$ \\
\hline 14 & Confederation Nationale Du Credit Mutuel \\
\hline 15 & Zentralverband Gewerblicher Verundgruppen E.V \\
\hline
\end{tabular}

They represent the $12 \%$ on the total of 124 comment letter taken into account in this study.

This response rate has a certain significance considering that this kind of subject do not usually participate massively to the IASB due process ${ }^{6}$.

In addition, we also noticed that there have been even higher rates of cooperatives' response to the FASB Preliminary Views and the EFRAG Discussion paper: respectively of $30 \%$ and $35 \%$.

With concern to our second hypothesis, we observed that all comment letters classified into the category of cooperatives were in opposition to the approaches proposed by the IASB. In particular they strongly criticized the Basic Ownership Approach. Next Graph presents in more detail the results of the first level analysis:

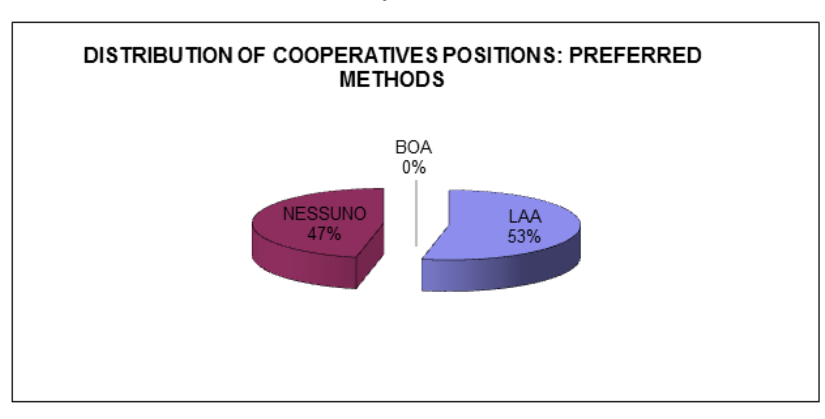

Graph 6. Distribution of cooperative positions

It is evident that cooperatives were united in criticizing

6 Occasional lobbyers send their comments when they have specific reasons for opposing to standard proposed. See Johnston-Jones (2006) [25].
- Information for employees

- Information for the general public

- Computation of tax [24] 
and opposing the IASB Discussion Paper, they welcomed instead the EFRAG document.

The majority of the letter analyzed (53\%) would support the Loss Absorption Approach by virtue of its neutrality. This percentage increases when we perform the second level of analysis: the $80 \%$ of letters sent by cooperatives show at least their interest for the method proposed by EFRAG.

From these results we deduce that there is a strong correlation between cooperative respondents and the preference for the Loss Absorption Approach.

Hp 2 is hence verified.

\section{Future Developments}

Classification of financial instruments as equity or liability is a complex and open issue. The IASB and FASB have tried to solve the problem by proposing a new approach.

Analyzing the comment letters, we have found two strong arguments against the Basic Ownership Approach.

First, the Basic Ownership Approach implies a very narrow definition of equity; this aspect mainly affects those firms belonging to the Continental European area in consideration of their laws with particular reference to the minimum capital and the maintenance capital rules.

Second, the distinction between equity and liability is particularly complex in co-operatives, as evidenced in the 2003 revision of IAS 32 and the subsequent issuing of IFRIC 2 in order to address problems in applying the revised IAS 32 to co-operatives. The application of the Basic Ownership Approach to other types of enterprises, including co-operatives can result in an entity without instruments classified as equity.

Thus it is not surprising that previous researches have claimed that cooperatives, due to their different ownership, governance and economic model, would even require a separate set of financial instruments classification principles, in order to better represent their own characteristics.

The IASB/FASB joint project on Financial Instruments with Characteristics of Equity has highlighted the complexity and the associated difficulty of drawing the line between liabilities and equity. While classification difficulties have been identified for investor-owned businesses (IOB), the inconsistency of the different approaches being considered is clearer when applied to classification of the financial instruments of co-operatives.

Nevertheless, according to the minutes of IASB meetings held on the specific issue of financial instruments with characteristics of equity, we have noted that the standard setter has abandoned the Basic Ownership Approach, as recommended by the majority of respondents.

Back in February 2008,the IASB took what was intended to be its first due process step towards a new Standard to replace IAS 32 by issuing the Discussion Paper entitled 'Financial Instruments with Characteristics of Equity'.

The IASB decided not to develop the Discussion Paper into an Exposure Draft, however, and the project was abandoned in favour of addressing what were felt to be greater priorities at the time.

In the IASB's December 2012 Feedback Statement on its 2011 'Agenda Consultation', the IASB indicated that it intends to reopen the debate on this area of classification by conducting a research project on it. The research project will focus on identifying financial instruments that are difficult to classify under the current requirements, or for which preparers or users question the classification. The Feedback Statement notes that any consideration of the distinction between liabilities and equity needs to be undertaken in conjunction with the Conceptual Framework work on elements of financial statements, and that the instruments identified in the course of the research will provide test cases for the staff developing the elements chapter of the Conceptual Framework. At the time of writing the IASB had not started the research project.

The IASB is abandoning any reference to entity and proprietary theories in the defining the objectives of financial reporting. This is a real obstacle to the clarification of equity-liabilities distinction, being the conceptual framework an appropriate place to choose the Equity Theory.

\section{REFERENCES}

[1] Financial Accounting Standard Board (1990): Discussion Memorandum, Distinguishing between Liability and Equity Instruments and Accounting for Instruments with Characteristics of Both, august 1990.

[2] Financial Accounting Standard Board (2007): Preliminary Views: Financial Instruments with Characteristics of Equity, November 2007.

[3] International Accounting Standard Board (2008): Discussion Paper, Financial Instruments with Characteristics of Equity, february 2008 .

[4] European Financial Reporting Advisory Group (2008): Discussion Paper, Distinguishing between liability and equity, January 2008.

[5] Kampmann E.-Schmidt M. (2008): Distinguishing between Equity and Liabilities, A View on FASB's and IASB's Approaches and an Introduction of the Loss Absorption Approach, available at: http://ssrn.com/abstract=1238071.

[6] Chow, Y. C. (1942) The doctrine of proprietorship, The Accounting Review, 17(2), pp. 157-16.

[7] Sprouse, R. T. (1957) The significance of the concept of the corporation in accounting analyses, The Accounting Review, 32(3), pp. 369-378.

[8] Paton, W. A. (1922) Accounting Theory (New York: Ronald Press).

[9] De Jong A.-Rosellon M.-Verwijmeren P (2006): The Economic Consequences of IFRS: The Impact of IAS 32 on Preference Shares in the Netherlands. Accounting in Europe, 


\section{$3,169-185$.}

[10] Engel E.-Erickson M.-Maydew E. (1999): Debt-Equity Hybrid Securities. Journal of Accounting Research, 2, 249-274

[11] Hopkins P. (1996): The Effect of Financial Statement Classification of Hybrid Financial Instruments on Financial Analysts' Stock Price Judgments. Journal of Accounting Research, 34, 33-50.

[12] Schroeder R.- Sevin D.- Schauer, D. (2006): The Economic Consequences of the Statement of Financial Accounting Standards (SFAS) No. 150. International Advances in Economic Research, 12, 498-504.

[13] Zeff, S. (1978): The Rise of "Economic Consequences". The Journal of Accountancy, 146, 56-63.

[14] Dechow P.M.- Hutton A.P.-Sloan R.G.B (1996): Economic Consequences of Accounting for Stock-Based Compensation. Journal of Accounting Research, 34 (3), 1-20.

[15] Fehr R.U.-Fülbier J. (2009) Economic Consequences of Discussed Changes in Lease Accounting - A Content Based Analysis of Due Process Comment Letters, paper presented at the 2009 EAA congress.

[16] Weber R. P. (1990): Basic content analysis, 2nd edition, Newbury Park, CA.

[17] Abrahamson E - Amir, E. (1996): The information content of the president's letter to shareholders. Journal of Business Finance \& Accounting, 23, 1157-1182.

[18] Smith M-Taffler R. J. (2000): The chairman's statement - a content analysis of discretionary narrative disclosures. Accounting, Auditing and Accountability Journal, 13, 624647.

[19] Weber R. P. (1990): Basic content analysis, 2nd edition, Newbury Park, CA.

[20] Yen A.C.-Hirst D.E.-Hopkins P.E. (2007): A Content Analysis of the Comprehensive Income Exposure Draft. Research in Accounting Regulation, 19, 53-79.

[21] Francis, J. R. (1987): Lobbying against proposed accounting standards: the case of employers' pension accounting. Journal of Accounting and Public Policy, 6(1), 35-57.

[22] Lopez-Espinosa G.-Maddocks J.-Polo-Garrido F. (2009), Equity-Liabilities Distinction: The case for Cooperatives. Journal of International Financial Management and Accounting, 20 (3), 274-306.

[23] Tandy P. R. -Wilburn N. L. (1992). Constituent participation in standard-setting: the FASB's first 100 statements. Accounting Horizons, 6(2), 47-58.

[24] Flower, J., (2004). European Financial Reporting: Adapting to a Changing World. Houndmills, Basingstoke, Hampshire,
UK: Palgrave Macmillan.

[25] Johnston D.-Jones D. (2006), How does accounting fit into a firm's political strategy, How does accounting fit into a firm's political strategy? Journal of Accounting and Public Policy, 2006, 25(2), 195-228.

[26] Financial Accounting Standard Board (2000): Exposure Draft, Proposed Amendment to FASB Concepts Statement No. 6 to Revise the Definition of Liabilities, October 2000.

[27] Financial Accounting Standard Board (2003): SFAS 150, Accounting for Certain Financial Instruments with Characteristics of both Liabilities and Equity, may 2003.

[28] International Accounting Standard Board (2008): Amendments to IAS 32 Financial Instruments: Presentation and IAS 1 Presentation of Financial Statements, Puttable Financial Instruments and Obligations Arising on Liquidation, February 2008.

[29] International Accounting Standard Board (2008): Discussion Paper, Financial Instruments with Characteristics of Equity, february 2008.

[30] Georgiou G. (2010): The IASB standard-setting process: Participation and perceptions of financial statement users. The British Accounting Review, 42, 103-118

[31] Georgiou, G. (2004): Corporate lobbying on accounting standards: methods, timing and perceived effectiveness. Abacus, 40(2), 219-237.

[32] Watts R. L.-Zimmerman, J. L. (1986): Positive accounting theory. Englewood Cliffs, NJ: Prentice Hall.

[33] Jones M. J. - Shoemake, P. A. (1994): Accounting narratives: A review of empirical studies of content and readability. Journal of Accounting Literature, 14, 142-184.

[34] Smith M-Taffler R. J. (2000): The chairman's statement - a content analysis of discretionary narrative disclosures. Accounting, Auditing and Accountability Journal, 13, 624647.

[35] Guay W.-Kothari S. P. - Sloan R. B (2003): Accounting for Employee Stock Options. American Economic Review, 93 (2), 405- 409.

[36] Khurana, I. K.-Loudder, M. L. B (1994): The Economic Consequences of SFAS 106 in Rate-Regulated Enterprises. The Accounting Review, 69 (2), 364-381.

[37] Stone M. - Ingram R. (1988): The Effect of Statement No. 87 on the Financial Reports of Early Adopters. Accounting Horizons, 2 (3), 48-61.

[38] Wasley, C.E.-Linsmeier, T. J. (1992): Further Examination of the Economic Consequences of SFAS. Journal of accounting research, $30(1), 156-164$ 